\title{
PERSEPSI AKUNTANSI SEKTOR PUBLIK VERSUS AKUNTANSI PEMERINTAHAN
}

Kariyoto

Dosen Prodi Keuangan dan Perbankan Universitas Brawijaya

\begin{abstract}
ABSTRAK
Persepsi yang disebarkan dalam pengajaran akuntansi pemerintahan Indonesia adalah akuntansi pemerintahan pengganti akuntansi sektor publik. Logika pengajaran disebarkan selalu dimulai dari bahasan pemerintahan yang bersih dan individu yang bersih. Definisi uang dalam pemerintahan yang bersih di Indonesia melibatkan hubungan antara eksekutif dengan legislatif, dana konsolidasi serta dana pinjaman nasional dalam menyusun rencana anggaran (RAPBN/RAPBD) yang sesuai. Masalah yang ada, pada umumnya, sektor publik digambarkan sebagai institusi pemerintah atau dengan kalimat yang lebih jelas pemerintah yang berkuasa, pemerintah negara, dan industri nasional perusahaan milik pemerintahan, badan hukum publik, perusahaan publik. Namun kata tersebut dirasa kurang tepat, sehingga frase pemerintah yang berkuasa masih menjadi perdebatan kontroversial dalam konteks demokrasi yang menyatakan bahwa rakyatlah yang paling berkuasa. Tujuan penulisan artikel ini menjelaskan pemahaman atau persepsi yang benar tentang akuntansi sektor publik. Tanpa mengabaikan pentingnya pemahaman teknik-teknik akuntansi di organisasi pemerintahan, pengajaran akuntansi sektor publik yang dikembangkan dalam kondisi yang berbeda.

Kata kunci: persepsi, akuntansi sektor publik, akuntansi pemerintahan
\end{abstract}

\begin{abstract}
Perceptions that are disseminated in Indonesian government accounting teaching are government accounting substitutes for public sector accounting. The logic of teaching spread always begins from the discussion of clean government and the clean individual. The definition of money in clean government in Indonesia involves the relationship between the executive and the legislature, the consolidated funds and the national loan funds in preparing the appropriate budget plan (RAPBN / RAPBD). The problem is, in general, the public sector is described as a government institution or with a clearer sentence of the ruling government, state government, and national industry of government-owned enterprises, public legal entities, public corporations. But the word is deemed inadequate, so the phrase of the ruling government is still a controversial debate in the context of democracy which states that the people are the most powerful. The purpose of the article explains the correct understanding or perception of public sector accounting. Notwith standing the importance of understanding accounting techniques in governmental organizations, public sector accounting teachings are developed under different conditions.

Keywords: perception, public sector accounting, government accounting
\end{abstract}

\section{PENDAHULUAN}

Akuntansi sektor publik didiskusikan dan diperdebatkan secara mendalam baru muncul belakangan ini. Keleluasan pembahasan bidang akuntansi sebagai satu sisi lain dari akuntansi mulai dirasa penting dalam pengajaran akuntansi di perguruan tinggi. Sebelumnya pembahasan akuntansi sektor publik ini dipersempit dan lebih dikenal sebagai akuntansi pemerintahan. Hal ini dapat dimaklumi karena orientasi pendidikan akuntansi Indonesia lebih berkiblat ke Amerika Serikat yang tidak mengenal akuntansi sektor publik. Perekonomian Amerika Serikat lebih menekankan pada sektor swasta. Peranan negara dalam perekonomian amat minimal. Pemerintah amat membatasi diri dalam kaitan program pemerintah dan ruang gerak institusi pemerinrah pusat dan daerah. Akibat dari sistem yang demikian, akuntansi sektor publik dibatasi ruang geraknya di sektor pemerintahan. Jadi akuntansi di pemerintahan Amerika Serikat lebih dikenal dengan akuntansi pemerintahan. Kondisi Indonesia tentunya berbeda dengan negaranegara lain. Peranan sektor publik dalam bentuk pemerintahan dan usaha-usaha yang dilakukan telah terbukti menjadi tulang punggung perkenomian negara selama lebih lima puluh tahun ini. Jadi pembatasan pembahasan akuntansi sektor publik pada pemerintahan akan berdampak kosongnya pengaturan praktikpraktik akuntansi di sekor publik itu sendiri. Sebagai langkah awal, penataan kembali akuntansi sektor publik tentunya perlu dilakukan. Salah satu alasan yang amat substantial adalah konsensus akan ruang lingkup akuntansi sektor publik.

Pendukung akuntansi pemerintahan memberikan alasan lain mengapa harus 
dikembangkan. Hal ini disebabkan oleh karakter akuntansi sebagai penyedia jasa yang relevan untuk berbagai jenis individu dan organisasi. Karakter ini memisahkan akuntansi dari perspektif makro, namun di lain pihak, perspektif ini membuka peluang untuk mengadopsi teknik ekonomi dan statistik. Akibatnya, akuntansi pemerintahan cenderung didefinisikan sebagai sistem pengukuran kinerja pemerintah. Akuntansi agar mendukung pemerintah atau dengan kata lain, dalam mempertangggungjawabkan terhadap keputusan sumber daya apa yang seharusnya dipenuhi untuk mencukupi kebutuhan militer (dan kebutuhan ekspor) serta kebutuhan kelompok sipil, diperlukan sumber daya dan pengetahuan yang rasional. Jadi praktik akuntansi pemerintahan yang benar mendapatkan dukungan yang luas dalam Orde Reformasi. Orde Reformasi ditandai dengan tuntutan pemerintahan yang bersih dan bebas korupsi, kolusi, dan nepotisme $(\mathrm{KKN})$ serta diberlakukannya Undang-Undang No 22 Tahun 1999 tentang Otonomi Daerah yang kemudian sekarang direvisi menjadi UU No 32 Tahun 2004 tentang Pemerintahan Daerah. Dari sisi teknik, berbagai kebijakan fundamental telah diluncurkan pada awal Kabinet Persatuan Nasional. Salah satu kebijakan yang penting adalah digantinya sistem penyusunan RAPBN/APBN yang semula menggunakan format single entry system menjadi double entry system dan perubahan mekanisme perencanaan anggaran yang semula top down approach menjadi mix antara top down approach dan bottom up approach. Praktik ini sudah dimulai di Indonesia pada tahun anggaran 1999/2000. Penulisan artikel ini dalam rangka memudahkan pemahaman diorganisasi sebagai berikut: (1) Pengembangan Organisasi Sektor Publik; (2) Kesadaran Dunia Pendidikan Tinggi; (3) Peran Akuntansi Bergeser; (4) Profesi sebagai Akuntan Sektor Publik; (5) Perkembangan Terakhir Akuntansi Sektor Publik di Negara Lain; (6) Titik Kritis dalam Praktik Akuntansi Sektor Publik; (7) Kesimpulan.

\section{Pengembangan Akuntansi Sektor Publik}

Pengembangan akuntansi sektor

publik, tanpa mengabaikan pentingnya pemahaman teknik-teknik akuntansi di organisasi pemerintahan, pengajaran akuntansi sektor publik dikembangkan dalam kondisi yang berbeda. Pertama, di tahun 1952, frase sektor publik untuk pertama kalinya diajarkan di dunia akademis (Kamus Inggris Oxford, edisi kedua, 1989, hal 779). Seorang ekonom, Suranyi-Unger, yang menghabiskan hidupnya di Hongaria, tetapi menulis di Amerika Serikat, menyajikan perbandingan sistem ekonomi dan mensintesisnya menjadi tiga kelompok, yaitu negara seperti Amerika Serikat yang menerapkan ekonomi liberal (kebebasan ekonomi), negara seperti Rusia yang mengadopsi ekonomi terpusat, serta negara seperti Inggris dan Perancis yang menerapkan kebebasan ekonomi barat secara tradisional, tetapi dalam dua dekade terdahulu telah beralih melaksanakan kompromi antara kebebasan dan perencanaan ekonomi sektor publik dengan persetujuan negara-negara tertentu yang menggunakan perencanaan ketimuran. Sektor publik negara pembentuk tidak hanya lebih kecil, tetapi juga berbeda kualitasnya. Sebagian besar negara-negara ini merencanakan tenaga kerja bagi ekonomi pemerintah dengan maksud membantu sektor swasta yang ditinggalkan (Brown \& Jackson, 1982).

Kedua, karakter organisasi sektor publik menunjukkan variasi sosial, ekonomi, politik, dan karakteristik menurut undangundang. Masing-masing memiliki perbedaan kekuatan dan tanggung jawab serta memperlihatkan contoh perbedaan pertanggungjawaban. Masing-masing berbeda tujuannya baik dalam hal keuangan maupun struktur organisasi. Perbedaan tersebut melukiskan betapa sektor publik berkembang sesuai dengan tekanan yang ada terhadap latar belakang sejarah yang dimiliki dan sumber dayanya, jadi memahami kinerja sektor publik sebaiknya dimulai bukan dari sisi teknis namun pada konsep dasar organisasi tersebut. Slogan Korps Pegawai Republik Indonesia (KORPRI), yang selalu digunakan dalam argumentasi debat di kelas, yaitu abdi rakyat atau pelayan masyarakat (sekarang merupakan organisasi pegawai negeri sipil yang berdiri sendiri) mencoba menggambarkan organisasi yang pada saat ini telah memperoleh pengakuan di Indonesia, serta bagaimana perbedaannya dengan pemerintah. Argumen yang biasanya digunakan untuk menetralisir pendapat ini adalah kemurahan hati. Inti dari kemurahan hati 
adalah kontribusi individu untuk kebutuhan publik sebagai bantuan terpenting dalam bentuk pajak. Substansi sukarela belum dapat diterima secara luas.

Ketiga, aktivitas organisasi sektor publik amat beraneka ragam. Sebagai contoh, mulai dibukanya sektor public berkompetisi dalam mekanisme pasar yang paling nyata, yaitu privatisasi, telah menyebabkan kebutuhan utama seperti gas, listrik, air, dan kepemilikan publik dilepaskan ke swasta (tetapi publik yang mengatur). Selain itu, aktivitas yang terus bertambah sekarang ini menghendaki keputusan didasarkan pada penawaran yang kompetitif dengan sektor swasta. Persaingan antara kontraktor dengan organisasi sektor publik untuk menyediakan. Hal tersebut dimulai dari persiapan anggaran sampai membersihkan perusahaan.

Empat, kondisi organisasi sektor publik amat mandiri, atau lepas dari mekanisme murni pasar, pemikir yang dominan saat ini masih berpihak pada pembatasan kompetisi terbuka. Sehingga terjadi pemisahan mekanisme manajemen kompetisi dan pasar ini, maka dengan penyedian jasa yang dipisahkan dengan konsumsi jasa tersebut. Sebagai contoh, pelayanan kesehatan dimana pemeliharaan rumah sakit menyediakan perawatan kesehatan yang paling murah bagi masyarakat. Akibatnya, program perubahan kepemilikan akan mengakibatkan pertentangan pasar dan mekanisme konsumsi produk organisasi sektor publik yang bersangkutan.

Kelima, fokus kesuksesan penyelenggaraan aktivitas publik adalah kompetensi manajemen, jiwa akuntansi sangatlah berperan dalam hal ini. Secara prinsip, akuntansi akan menjadi alat pengendali dari manajer, memunculkan konsistensi seorang manajer bertanggung jawab tidak hanya untuk aktivitas tersebut, tetapi juga untuk manajemen keuangan dari aspek pengecualian anggaran belanja. Misalnya, dalam manajemen sekolah negeri di daerah, kepala sekolah diberikan anggaran belanja operasi berdasarkan jumlah siswa yang belajar kemudian menjalankannya di sekolah serta mengendalikan anggaran belanja mereka. Begitu pula di pemerintahan pusat, banyak fungsi menteri yang membawahi departemen diberi wewenang untuk mengusulkan rencana anggaran yang diperlukan untuk menjalankan program departemen dan bertanggung jawab terhadap fungsi dan operasional yang terbatas dalam suatu anggaran belanja tertentu. Jadi fokus pengajaran dikembangkan dari teknis pencatatan ke analisis kebijakan manajemen sektor publik.

Keenam, kondisi proses pertanggungjawaban yang dilakukan oleh badan-badan sektor publik masih bersifat umum. Kompetensi khusus dialihkan ke wakil rakyat di DPR/DPRD, sebagai penentu kualitas pertangjawaban manajemen organisasi sektor publik. Dalam proses penanggungjawaban berbagai variasi formal dan informal jaringan kerja berdampak secara langsung ke alur aktivitas organisasi sektor publik. Sebagai contoh, proses kerja menteri di pemerintah pusat, pelayanan umum, pemilihan anggota di daerah, penunjukkan panitia, lembaga swadaya masyarakat, pers, kelompok oposisi, dan lainnya. Mekanisme yang terjadi amat tergantung pada struktur organisasi kelompok secara umum dan proses dinamika komunikasi yang terjadi. Oleh sebab itu, pengelola organisasi sektor publik harus selalu mempunyai kesadaran terhadap jalan perubahan dan siap untuk mengubah tanggapan mereka terhadap perubahan tersebut.

Badan sektor publik untuk bertanggung jawab ke DPR/DPRD ada banyak cara yang dapat digunakan. Misalnya, Menteri Kesehatan yang mempertanggungwabkan tugasnya secara langsung kepada presiden dan publik (yang diwakili DPR). Selain itu, industri nasional, badan hukum publik, dan badan-badan publik non pemerintah (BUMN/BUMD), termasuk pemegang wewenang pelayanan kesehatan bertanggung jawab terhadap departemen pemerintah sesuai tujuan dasar mereka. Kepala Daerah menyajikan satu contoh unik yang berbeda, yaitu meskipun bertanggung jawab kepada DPRD Tingkat I, mereka juga bertanggung jawab kepada menteri dalam negeri dan masyarakat di wilayahnya. Pertanggungjawaban rangkap kepada menteri dalam negeri dan DPRD serta publik ini masih dalam konteks negara kesatuan damn Presidenlah yang berkuasa.

Perbedaan bentuk pertanggungjawaban kepada DPR/DPRD mengakibatkan perbedaan tujuan khusus masing-masing organisasi sektor publik. Tujuan khusus pemerintah pusat 
merupakan kesepakatan dan ketetapan dengan lembaga legislatif (DPR/MPR). Di badan publik lainnya, tujuan operasional yang detail lebih diartikan sebagai tanggung jawab pelaksana anggaran (pihak eksekutif) yang ditunjuk. Tujuan operasional ini biasanya didukung oleh berbagai ketetapan-ketetapan organisasi, seperti keputusan presiden, keputusan menteri, peraturan pemerintah, dan lainnya. Walaupun begitu, ketentuan operasional bisa merupakan turunan dari instrumen undang-undang, ketetapan MPR, APBN, dan keputusan legislatif lainnya.

Pemerintahan daerah dalam mekanisme pertanggungjawaban melalui standarisasi pelayanan publik, seperti pendidikan dan pelayanan sosial, ditetapkan oleh Dewan Perwakilan Rakyat Daerah. Di sini terjadi pembagian tanggung jawab sebagai penentu standar regulator adalah DPRD, dan sebagai operator adalah Kepala Daerah yang menyediakan pelayanan yang diinginkan dengan tujuan dan tanggung jawab yang jelas. Pengaruh menteri dan departemen-departemen di pemerintah pusat masih terasa kuat dalam tahap perencanaan program. Tekanan kelompok-kelompok di daerah, seperti organisasi massa di daerah, komisi perdagangan, kelompok-kelompok aksi, partai politik di daerah, LSM di daerah, dan lain-lain memberikan arahan terbatas untuk urusan daerah. Sebagai konsekuensinya, Kepala Daerah harus memiliki kemampuan untuk menekan sumber daya yang bervariasi tersebut. Tekanan ini berubah-ubah seiring dengan kekuatan dan kelemahan tekanan sumber daya yang ada. Enam alasan di atas telah berkembang, sehingga kecenderungan perubahan ke akuntansi sektor publik menjadi lebih pasti. Dalam berbagai diskusi, permasalahan perubahan kebijakan pengajaran sistim informasi akuntansi ini sebenarnya tidak perlu diperdebatkan. Alasannya adalah bahwa materi dan teknik pengajaran lebih menentukan. Artinya, yang perlu dibicarakan adalah apa yang diajarkan dan bagaimana menyampaikan. Nama mata kuliah akuntansi sektor publik dan akuntansi pemerintahan tidak akan berpengaruh apabila struktur mata kuliah tersebut tidak jelas.

\section{Kesadaran Dunia Pendidikan Tinggi}

Dunia pendidikan tinggi di pertengahan tahun sembilan puluhan, memulai adanya kesadaran untuk mengubah mata kuliah akuntansi pemerintahan mulai muncul. Pengakuan akan masalah pemerintah yang terlalu besar dan sulitnya proses pengawasan mulai muncul. Selain itu, program pemerintah yang selama dua puluh tahun berorientasi ke pertumbuhan, mulai bergeser dengan mempertimbangkan faktor pemerataan. Sementara itu, globalisasi telah mempengaruhi sikap masyarakat terhadap pemerintah dan infrastruktur operasional pemerintahan itu sendiri. Demikian juga, kesadaran akan perlunya dikembangkan pelayanan publik, seperti telekomunikasi dan listrik, mulai diungkap di berbagai media massa. Kondisi ini diperkuat dengan semakin kuatnya tuntutan LSM-LSM nasional maupun internasional terhadap mekanisme pelayanan publik. Munculnya studi akuntansi sektor publik di kurikulum nasional merupakan hal yang tepat untuk menjawab perubahanperubahan yang terjadi di masyarakat Indonesia saat ini. Secara teoritis, Akuntansi Sektor Publik merupakan bidang akuntansi yang mempunyai ruang lingkup lembagalembaga tinggi negara dan departemendepartemen di bawahnya, pemerintahan daerah, yayasan, partai politik, perguruan tinggi dan organisasi-organisasi nonprofit lainnya. Dari berbagai diskusi yang telah dilakukan, didapatkan: Organisasi sektor publik dapat dibatasi dengan organisasi-organisasi yang menggunakan dana masyarakat, sehingga perlu melakukan pertanggungjawaban ke masyarakat. Akuntansi sektor publik di Indonesia, mencakup beberapa bidang utama, yakni: a. Akuntansi Pemerinrah Pusat; b. Akuntansi Pemeriruah Daerah; c. Akuntansi Parpol (Partai Politik) dan LSM, d. Akuntansi Yayasan. e. Akuntansi Pendidikan dan Kesehatan: puskesmas, rumah sakit, dan sekolah. f. Akuntansi Tempat Peribadatan: masjid, gereja, vihara, kuil.

Masyarakat Indonesia dalam dekade dua tahun terakhir ini, mengalami perubahan yang cukup mendasar dan besar, yang ditandai dengan meningkatnya keinginan akan akuntabilitas dan transparansi kinerja terhadap pengelolaan sektor publik. Perlawanan terhadap budaya manipulasi baru saja dimulai dengan berakhimya era 
pemerintahan yang mengutamakan stabilitas. Istilah reformasi merupakan cetusan untuk mendudukkan kembali keseimbangan antara pembangunan fisik dan pembangunan nilai. Akibatnya, reformasi menjadi lebih menekankan pembangunan nilai yang diungkap dalam good governance.

Pemerintahan yang bersih diungkapkan dan diinterprerasikan sebagai perwujudan indikator kejujuran pemerintah. Selama dua puluh tahun yang lampau, kejujuran pemerintah lebih diartikan sebagai stabilitas pemerintah. Sedangkan di masa reformasi, kejujuran diartikan sebagai pemerintah yang bersih, akibatnya, mekanisme manipulasi yang dipraktekkan di masa itu harus diganti dengan mekanisme transparansi.

\section{Peran Akuntansi Bergeser}

Peranan akuntansi telah bergeser ternyata tidak membuat akuntansi sebagai mekanisme pertanggungjawaban. Perubahan politik dan krisis ekonomi telah menyebabkan munculnya kesadaran baru di kalangan masyarakat Indonesia. Fungsi akuntansi saat ini, diharapkan menjadi turunan dari perkembangan tuntutan masyarakat terhadap bidang akuntansi untuk memajukan sektor publik. Akuntansi di masa awal reformasi telah menghadapi "kehinaan" yang secara eksplisit terbukti dengan ditunjuknya akuntan asing untuk melakukan due dilligence dalam berbagai sektor publik dan kasus-kasus skandal. Terlepas dari alasan untuk membangkitkan kepercayaan asing terhadap perekonomian kita, fakta itu menunjukkan rendahnya kredibilitas akuntan kita termasuk di dalamnya akuntan sektor publik di mata dunia intemasional. Akibatnya, praktik kejujuran akuntan harus ditingkatkan. Etika pemeriksaan akuntan harus ditegakkan, dalam artian pelanggaran bukan hanya herdampak terhadap keanggotaan profesi, namun kerugian yang ditimbulkan juga bisa diambil tuntutan di jalur hukum.

Penegakan etika profesi akuntan pemeriksa saat ini menjadi suatu hal yang mendesak. Selama ini, tuntutan dibatasi hanya oleh profesi, dalam artian sepanjang aturan profesi dipatuhi akuntan dianggap sudah memenuhi kewajiban baik secara profesi maupun kemasyarakatan. Hal ini telah dinilai tidak wajar. Sehingga, masyarakat menuntut agar akuntan bisa dituntut di jalur hukum.
Profesionalisme profesi, dalam hal ini terkait dengan kejujuran, keahlian dan pribadi, telah dituntut untuk dapat dibawa sebagai kredibilitas profesi di mata prosedur hukum masyarakat. Ini berarti yang diminta sebenarnya adalah perubahan dari sekedar moralitas menjadi realitas hukum masyarakat. Salah satu ciri khas gerakan reformasi adalah tuntutan akan pemerintah yang bersih. Akuntan sebagai suatu profesi dimima untuk terlibat secara aktif terkait dengan pelaksanaan transparansi ekonomi. Secara umum, pemahaman/keahlian penyusunan sistem keuangan merupakan kompentensi akuntansi. Akuntansi sektor publik yang diharapkan lebih ditekankan pada sistem dan pemeriksaan akuntansi. Sistem akuntansi sektor publik yang selama ini dikembangkan lebih melayani karakteristik persaingan swasta. Ini tentunya merupakan kesalahan besar karena karakter dan evaluasi kinerja publik amat berbeda dengan yang ada di swasta.

Pengukuran prestasi dan kinerja sektor publik merupakan titik berat pengembangan akuntansi sektor publik. Penekanan terhadap efisiensi keuangan dan efektivitas manajemen akan menjadi dua titik awal fokus pengembangan bidang akuntansi manajemen sektor publik ini. Jadi, tuntutan masyarakat terhadap pengembangan peranan akuntansi di sektor publik menjadi suatu yang harus dijawab. Lebih dari 5000 akuntan dan pemerhati akuntansi berkarya di sektor publik. Namun peran profesional mereka selama ini belum dimaksimalkan. Rapatkan barisan, tetapkan tujuan tebarkan ide untuk peningkatan peran dan fungsi. Dalam kebersamaan langkah dan tujuan peningkatan mandat masyarakat pada profesi dilakukan. Kebersamaan itu akan lebih indah lagi untuk kita wujudkan dalam bagian utuh dari wadah monumental ini.

\section{Profesi Sebagai Akuntan Sektor Publik}

Praktik akuntansi sudah berlangsung cukup lama dalam peradaban manusia dan sudah menjadi bagian dari sifat manusia (Parker dan Yamey, 1994). Disiplin akuntansi mulai diakui sejak awal abad ke-19 di lnggris. Disiplin ini muncul dari dunia praktik, bukan di laboratorium sosial di universitas (Whittington,1986). Oleh sebab itu, profesi akuntan harus dipahami dari kondisi praktik 
akuntansi. Profesi akuntan dengan disiplin akuntansinya dianggap oleh Anglo-Amerika sangat mempengaruhi pertumbuhan bisnis di seluruh dunia. Beberapa negara, seperti Rusia dan negara-negara Eropa Timur, yang dulunya tidak terpengaruh, mulai mengalami perubahan yang signifikan dalam bidang akuntansi. Perkembangan ini tentunya bukan tanpa kritik tethadap kondisi yang selalu berkembang. Kontroversi dalam industri dan perdagangan telah timbul akibat perdebatan penerapan teknik akuntansi. Walaupun demikian, pengembangan pendekatan sosiologi telah menjadi penawar dengan kritikkririk yang radikal. Selayaknya suatu bidang ilmu, kekuatan terbesar akuntansi adalah kelemahan utamanya. Uang merupakan alat tukar penengah dan sumber kekayaan, sehingga akuntan dibayar untuk mengembangkan kekayaan orang lain. Kelompok sosial di mana uang (dalam pemahaman ini) berperan penting, akan menentukan nilai disiplin akuntansi, tetapi kelompok sosial di mana uang tidak memainkan peranan ini (seperti Uni Soviet sebelum runtuh) akuntansi tidak akan dianggap penting. Dengan demikian, kritik-kritik terhadap peran disiplin akuntansi akan lebih mudah dijawab.

Interpretasi akuntansi sebagai uang, ternyata membawa kelemahan utama bidang ini. Perubahan nilai nominal uang antar waktu dan antar mata uang negara yang berbeda menyebabkan interpretasi peran akuntansi tergantung pada karakter pasar. Dengan kata lain, akuntansi sangat tergantung pada waktu dan tempat. Oleh sebab itu, perbandingan akuntansi antar organisasi menjadi lebih sulit, terutama terkait dengan sifat kontinjensi. Atau, dengan kata lain, akuntansi dipergunakan sebagai landasan penilaian atau pengambilan keputusan di dalam organisasi. Jadi, karakter konsisten dan entitas perlu dikembangkan dalam berbagai aktivitas pengambilan keputusan. Konsekuensi dari kondisi-kondisi khusus adalah timbulnya pertanyaan terhadap filosofi akuntansi itu sendiri. Apakah akuntansi merupakan suatu ilmu atau semata-mata seni? Apabila akuntansi merupakan ilmu, maka pertanyaannya adalah tentang karakter akuntansi dalam kasus-kasus khusus. Apabila akuntansi itu seni, berbagai gejala umum dapat ditelusuri. Kontradiksi ini masih terus berlangsung.

Profesi akuntan berkembang dan menunjukkan bahwa di dunia praktik, akuntansi sukses berkompetisi dengan konsultan manajemen. Ini memunculkan perluasan batas-baras disiplin akuntansi. Tanpa mengubah karakter inti disiplin akuntansi, utilitas akuntansi telah berkembang. Jadi, para akademisi bekerja untuk mengobservasi penggunaan akuntansi dalam mengelola perusahaan dan pencapaian kesejahteraan masyarakat. Ini berarti fungsi akuntansi dalam pelaporan akan semakin penting. Keterkaitan profesi ini dengan mata rantai uang telah menyebabkan penyebaran yang cepat ke berbagai organisasi. Pada awalnya, profesi akuntansi dimunculkan dalam organisasi seperti Institute of Chartered Accountants (di Inggris dan Wales) yang didirikan pada tahun 1880. Perkembangan ini diperkuat oleh lembaga The Corporate Treasurers and Accounting Institute pada tahun 1885. Dua lembaga ini merupakan lembaga bentukan pemerintah daerah. Namun demikian, tujuan sebenarnya dari pembentukan dua lembaga tersebut adalah mempresentasikan akuntansi di perusahaan kota praja. Selanjutnya muncullah organisasi Chartered Institute of Publik Finance and Accounting (Sowerby, 1985) yang mensertifikasi para pekerja di sektor publik. Jadi legitimasi subdisiplin akuntansi sektor publik resmi ada.

Perusahaan di Inggris, pada akhir abad 19, didirikan oleh Pemerintah Kota Praja untuk memenuhi kebutuhan masyarakat. Kebijakan ini diwarnai oleh dogma sosialis Gones, (1992b). Persepsi masyarakat dialihkan bahwa penyelenggara kebutuhan adalah perusahaan utilitas, bukan pemerintah daerah. Proses pelayanan ini menjadi sektor publik terbesar, di luar sektor pertahanan dan keamanan. Akuntansi nampaknya dieksplorasi secara serius dalam menciptakan proses pengambilan keputusan yang rasional. Akuntansi di pemerintah daerah atau kota praja dan perusahaannya disebut "akuntansi sektor publik".

Perusahaan kota praja pada pertengahan abad 12, dengan pertimbangan efisiensi, disatukan ke dalam industri nasional dan sistem pelayanan nasional, seperti kesehatan. Kondisi ini justru memperkuat 
akuntansi sektor publik yang akhirnya dieksplorasi ke pengelolaan perusahaan secara profesional dan global. Proses sertifikasi mulai dilakukan pada tahun 1926. Perusahaan Broadcasting menjadi industri nasional pertama yang mendapatkan sertifikasi laporan keuangan. Oleh sebab itu, audit laporan keuangan diatur dengan peraturan pemerintah, di mana audit harus dilakukan oleh akuntan bersertifikat (registered accountant). Kebijakan ini menyebabkan berbagai aktivitas baru, seperti penyusunan silabus, perancangan kertas kerja, dan sosialisasi ke industri dan pemerintah daerah. Pada awal tahun 1970-an, profesi akuntan di lnggris mulai menurun dengan perubahan The Institute of Municipal Treasures and Accountants ke The Chartered Institute of Publik Finance and Accountancy. Namun demikian, istilah "sektor publik" menjadi lebih disukai. Istilah ini membuka representasi akuntan profesional di luar sektor swasta. Akibatnya, akuntansi sektor publik menjadi wadah interdisipliner tentang materi kesejahteraan masyarakat. Dan pada saat yang sama, bidang akuntansi manajemen sektor publik dan audit sektor publik diubah orientasinya ke pelayanan publik.

Perkembangan profesi akuntan sektor publik di Indonesia belumlah semaju perkembangan profesi akuntan di lnggris. Bahkan dibandingkan dengan profesi akuntan lain, seperti akuntan sektor swasta, akuntansi sektor publik masih ketinggalan. Hal ini berkaitan dengan sistem sentralisasi pemerintahan yang berdampak pada penggunaan sistem dan prosedur pelaporan keuangan yang seragam dan terpusat. Dengan berubahnya orientasi politik dan ekonomi di era reformasi, organisasi profesi akuntan-ikatan Indonesia (IAI) mulai memunculkan Kompartemen Akuntan Sektor Publik. Kompartemen mewadahi para pekerja bidang akuntansi dan akuntan yang bekerja di bidang organisasi sektor publik. Dan tentunya, permasalahan standarisasi praktik-prakrik akuntasi sektor publik di Indonesia harus dipecahkan. Selain itu, mitra kerja Kompartemen Akuntan Sektor Publik juga telah dibangun dalam Kompartemen Akuntan Pendidik yang disebut Kajian Pendidik Akuntansi Sektor Publik. Informasi aktivitas pengembangan ilmu dan dialog akuntansi sektor publik telah disebarluaskan di Jurnal
Akuntansi dan Keuangan Sektor Publik, serta homepage-nya.

Dari pembahasan di atas, proses pengembangan bidang akuntansi sektor publik saagat dipengaruhi oleh kapasitas dan tujuan kebijakan ekonomi, sehingga aspek budaya, sosial, dan politik ekonomi menjadi dominan. Selain itu, orientasi pengelolaan organisasi sektor publik akan mengubah arah pengembangan organisasi akuntansi, Namun, heterogenitas bidang sektor publik akan menjadi alasan logis untuk menciptakan kompleksitas bidang akuntansi sektor publik. Ini berarci, kunci pemecahan permasalahan akuntansi sektor publik adalah penyederhanaan yang logis dalam pengelolaan sektor publik. Interaksi antardisiplin dalam akuntansi sektor publik memungkinkan proses bench mark dalam penerapa teknik dan definisi unit fisik output penjualan untuk pelanggan. Misalnya, penerapan analisis volume-harga-laba, standar harga, keuntungan dan kerugian, serta pengembalian modal. Terkait dengan itu semua, proses adopsi dilakukan dalam konteks peningkatan prestasi untuk mewujudkan kesejahteraan masyarakat.

\section{Perkembangan Akuntansi Sektor Publik Di Negara Lain}

Inggris yang berpengalaman dapat dijadikan acuan dalam mempelajari perkembangan administrasi publik di era tahun 1980-an sampai dengan tahun 1998, yang berkembang seiring dengan tuntutan untuk penyelenggaraan pemerintahan yang lebih akuntabel. Pandangan bahwa efisiensi sektor pemerintahan dapar diukur telah disuarakan sejak tahun 1968. Sebagai contoh, laporan Fulton merekomendasikan untuk menetapkan unit yang bertanggung jawab dalam organisasi pemerintahan, yaitu jika outputnya dapat diukur/dibandingkan dengan biayanya atau kriteria yang lain, dan jika para pelaksana secara individu dapat dimintai pertanggungjawaban atas kinerjanya. Tanpa mengingkari kesulitan dalam penetapan pengukuran kinerja ini, konsep ini terus menggelinding dengan cepat karena beberapa alasan, yakni faktor kecurigaan akan adanya inefisiensi birokrasi, semakin terbatasnya sumber daya, perkembangan teknologi, dan kegagalan reformasi institusional di tahun 1970-an. Selain itu, pemerintah Amerika 
Serikat juga melakukan beberapa upaya dalam mendorong tercapainya administrasi publik yang lebih baik seperti yang diilhami oleh pemikiran Gaebler dan Ted (1992) dalam bukunya yang disebut dengan Reinventing Government.

Beberapa contoh proyeksi mewiraswastakan kepemerintahan ini telah dilakukan di beberapa pemerintahan Federal, Negara Bagian maupun pemerintahan kota. Sebagai contoh, selama ini pemerintah Amerika mempunyai monopoli dalam memproduksi senjata dengan alasan bahwa sangat riskan bagi pihak swasta untuk melakukan hal yang cukup vital ini. Namun dalam kenyataannya, tidak seorang pun warga Amerika Serikat membiarkan pemerintahannya memproduksi senjata.

\section{Titik Kritis Dalam Praktik Akuntansi Sektor Publik}

Melihat pentingnya reformasi akuntansi, penerapan perspektif organisasi atau yang dikenal dengan menemukan kembali pemerintahan, harus dilandasi dengan menemukan kembali peranan akuntansi. Praktik akuntansi sektor publik (Penlebury, 1992) di Indonesia mempunyai empat titik kritis sebagai berikut.

Pertama, praktik pertanggungjawaban akuntansi yang layak. Prosedur penghasilan dan pembayaran dari pusat pertanggungjawaban organisasi sektor publik dapat dilakukan dengan pemenuhan otorisasi, baik dari DPR/DPRD atau komisaris. Kadangkala proses otorisasi ini dihasilkan dari proses demokrasi melalui pengambilan suara/voting.

Kedua prinsip bruto, seluruh penghasilan dibayarkan bruto, dan biaya yang terjadi dibebankan sebagai pengurang penghasilan dan harus dilaporkan secara lengkap ke setiap pusat pertanggungjawaban yang terkait.

Ketiga periodikal, semua pengeluaran harus dipertanggungjawabkan per periode, sehingga otorisasi pengeluaran akan dinilai berdasarkan prestasi periode terkait. Kelebihan dana di atas pengeluaran dapat diketahui dan dikembalikan ke manajemen pusat per tanggungjawaban.

Keempat spesifikasi, pengeluaranuntuk tujuan khusus harus dilandasi oleh persetujuan DPR/DPRD atau komisaris.
Konsep by exception/pengecualian ini harus diatur dalam peraturan tersendiri tanpa mengabaikan tingkat pencapaian prestasi manajemen organisasi sektor publik yang terkait.

Tipe praktik pertama lebih menekankan keseimbangan antar proses perencanaan dan pertanggungjawaban. Dalam proses perencanaan, faktor pengendalian kas menjadi perhatian utama. Kas seringkali diartikulasikan sebagai dampak perubahan harga atau nilai ekonomi riel. Anggaran belanja merupakan hasil dari harga kali kuantitas, di mana kuantitas adalah kuantitas dari masukan. Ketika inflasi angka ganda terjadi pada awal tahun 1970-an, kesulitan pengendalian adalah volume anggaran belanja. Anggaran belanja secara implisit mengalami kesulitan untuk meratakan kuantitas pada semua bagian. Akibatnya, perubahan antara pemasukan dan pengeluaran lebih besar daripada yang dialokasikan pada anggaran belanja, sehingga anggaran terpaksa diubah untuk mempertahankan kuantitas implisit yang dibeli. Praktik ini diharapkan akan menunjukkan prestasi di mana perubahan harga bergerak ke bawah harga umum.

Namun yang sering terjadi sebaliknya, di mana volume anggaran belanja cenderung menjadi pedoman harga umum sehingga terjadilah institusionalisasi inflasi. lni bisa terjadi akibat peraturan pemerintah atau pengelolaan anggaran yang. tidak konservarif. Dari hasil observasi, pengendalian anggaran belanja sering didasarkan pada harga fluktuasi yang umumnya berubah cepat, bukan pada harga prestasi yang di bawah harga umum (Say, November Prices). Sebagai alternatif dari dasar volume anggaran belanja adalah pendekatan dasar kuantitas uang tunai yang diterapkan untuk menata anggaran belanja sebanyak uang tunai implisit dengan kuantitas barang atau pelayanan jasa yang dibeli. Pendekatan ini dilandasi pada asumsi akurasi penataan anggaran. Pendekatan ini akan menyebabkan penetapan anggaran untuk pos yang terkait langsung dengan masyarakat, seperti tunjangan kesehatan dan pensiun, akan lebih diperuntukkan oleh tunjangan kehidupan sehari-hari. Atau, dengan kata lain, pembengkakan kebutuhan kas sangat mungkin terjadi. Oleh sebab itu, manajemen sering memisahkan pos-pos tersebut dari kebijakan 
anggaran belanja dan membuat ketetapan tersendiri, seperti anggaran subsidi.

Pemerintah disisi lain, proses pertanggungjawaban sering kali diperlakukan sebagai hal seremonial. Pada awal era reformasi, tahap pertanggungjawaban digugat. Di pusat, kepala pemerintahan akan dievaluasi setiap tahunnya oleh Sidang Tahunan Majelis Permusyawaratan Rakyat (MPR). Di daerah, kinerja kepala daerah mulai dievaluasi secara terbuka dalam forum sidang Dewan Perwakilan Rakyat Daerah (DPRD). Ini berarti tuntutan pelaporan eksternal semakin meningkat. Atau, dengan kata lain, keseimbangan peranan perencanaan dan pertanggungjawaban akan menjadi ciri pengelolaan organisasi sektor publik di era reformasi ini. Sebaiknya kejelasan konsep penanggungjawaban harus dijabarkan secara terbuka sebelum pekerjaan dimulai. Berbagai indikator keuangan dan nonkeuangan harus dirumuskan, sehingga bisa menjawab berbagai keraguan tentang optimalitas manfaat laporan keuangan. Selain itu, lekatnya proses pertanggungjawaban dengan karakter setiap organisasi sektor publik juga perlu diperhatikan untuk akomodasi perbedaan antar berbagai organisasi sektor publik.

Faktor akuntabilitas amat penting dalam dari penjelasan di atas, pengelolaan dana masyarakat. Praktik pemilihan program dengan dana masyarakat perlu dikembangkan dalam konteks visi kesejahteraan masyarakat. Ini berarti akuntabilitas manajemen kesejahteraan masyarakar sangat menentukan perkembangan Akuntansi Sektor Publik (ASP).

\section{KESIMPULAN}

Pemerintah bertugas mengendalikan akuntansi sektor publik, bukannya seperti mendayung sebuah perahu (E.S.. Savas, 2000). Di berbagai negara lain filosofi ini benarbenar diterapkan. Di St. Paul, Minne Sota, George Latimer (1975) yang terpilih sebagai walikota berusaha memulihkan ekonomi kota tersebut dengan mengubah sumber daya kota yang ada dengan cara mengkombinasikannya dengan berbagai sumber daya dari sektor privat, meminta bantuan dana, dan membawa pengembang masuk. Selain itu, dia juga melakukan usaha lain yang diserahkan kepada swasta seperti mendirikan sarana perumahan yang terjangkau dan menggunakan jasa tenaga kerja sosial bernilai jutaan dollar. Hasilnya, Latimer mampu meningkatkan wibawa pemerintahannya walaupun ada pengurangan karyawan sebanyak 12\%, menjaga anggaran, mempertahankan tingkat penumbuhan pajak propertinya di bawah inflasi, serta mengurangi hutang kota. Keadaan tersebut sangat berbeda pengeloaan akuntansi sektor public yang ada di Indonesia. Pemerintah kota sangat bergantung pada pajak, iklan dan pungutan lain. Para pengembang kurang berminat karena kondisi sosial politik yang tidak stabil dan tingkat inflasi yang tinggi. Selain itu, pemerintah kota sangat bergantung pada pemerintah pusat. Tingginya pengaruh politik di Indonesia terhadap sistem Organisasi, Sterling (2004) berpendapat bahwa hampir semua masalah praktis yang dihadapi dalam praktik akuntansi bisa dipecahkan dengan teori. Ketika sebuah masalah muncul, isu sebenarnya adalah bahwa manajemen tidak sependapat dengan pandangan akuntansi. Dengan demikian, masalahnya bukan teknis tetapi merupakan masalah politis. Sebuah studi yang dilakukan oleh Watts and Zimmerman (1978) memunculkan pertanyaan mengapa suatu perusahaan membelanjakan sumber daya untuk mempengaruhi standar akuntansi. Hasil studi tersebut memperlihatkan bahwa manajer mempunyai alasan yang kuat untuk menginginkan kepastian prosedur akuntasi dibanding dengan yang lain. Hipotesis dari investigator mengarahkan bahwa karena pajak, politik, dan pertimbangan kebijakan, manajer dari perusahaan besar memilih standar akuntansi, karena laporan pendapatan harus dikurangi. Manajemen cemas bahwa pendapatan yang besar akan mengundang pemerintah untuk melakukan intervensi langsung.

Badan-badan pemeriksa seperti BPK apa yang dapat dilakukan, jika menghadapi masalah ini dalam manajemen sektor publik? Inti dari masalah tersebut adalah bahwa akuntan memberikan respons tanpa adanya kekuatan untuk menekan keputusan pihak pemerintah. Profesi akuntan akan memberikan respons untuk memastikan bahwa laporan keuangan yang telah dipublikasikan sesuai dengan standar yang ditetapkan.Tetapi hal itu tidak diterima secara legal oleh profesi akuntan, karena pendapat auditor yang terdiri dari adverse, qualified, dan disclimer dalam laporan hasil pemeriksaan atas laporan keuangan, jarang digunakan. Apa yang diharapkan oleh auditor sektor publik ketika menghadapi keadaan sulit ini? Tindakan yang dapat dilakukan adalah memperbaiki citra profesi akuntan atau menghindar dari tanggung jawab. Selain itu, ada pernyataan sederhana bahwa lingkungan akuntansi itu merupakan arena politik. Angka- 
angka dalam laporan keuangan mempunyai dampak sosial, di mana perkiraan dan tingkah laku dari banyak orang akan terpengaruhi. Akan tetapi, beberapa akuntan berpendapat bahwa proses standar yang telah diformulasikan menjadi faktor politis.

Professors May dan Sundem State ( 1976) menyatakan, visi kesejahteraan sosial dari laporan akuntan sektor publik secara jelas dapat diakui. "Bagaimanapun juga, .... melihat kenyataannya yang terjadi sekarang, lembaga-lembaga yang mengikrarkan sebagai lembaga independen sedikit banyak juga tersentuh oleh politik pemerintahan. Bahkan BPK yang menjadi salah satu lembaga tinggi negara antirasuas juga tidak dapat dipungkiri terintervensi oleh pemerintah, terutama di masa Orde Baru. Sekarang masalahnya adalah apakah standar tersebut seharusnya dalam standar sektor privat atau sektor publik. Penelitian yang dilakukan oleh Professors Ronen dan Schiff (I978) yang telah menyebarkan kuesioner sebanyak 1.329 kepada para responden seperti beberapa eksekutif perusahaan besar, akuntan sektor publik, akademisi akuntan, analis keuangan, pengacara, dan bankir menyimpulkan bahwa 91,9\% responden menyatakan bahwa standar seharusnya dibuat sesuai dengan format untuk sektor privat. Ini berarti standar yang dibuat untuk sektor publik seharusnya harmonis dengan praktik yang ada untuk sektor swasta.

\section{DAFTAR PUSTAKA}

1. Brown dan Jackson. 1982. Political Power. Cornell University Press.

2. E.S. Savas. 2000. Privatization and PublicPrivate Partnerships. Chatham House Publishers/ Seven. Bridges Press, New York, 2000.

3. Gaebler and Ted. 1992. Reinventing Government: How the Entrepreneurial Spirit is Transforming the Public Sector. Boston: AddisonWesley-Publ. Co.

4. George Latimer . 1975. Was an escaped slave whose case became a .... New Haven: Yale University Press.

5. Gones. 1992b. Perbedaan antara Laporan Keuangan Sektor Publik dengan Laporan Keuangan Sektor Swasta. Yale University Press. Issue 5, pp 147-150.

6. May, R.G. and G.L. Sundem. 1976. Research for Accounting Policy. Graduate School.

7. Parker dan Yamey. 1994. Karakteristik dan Lingkup sector Public. mnchaniago.blogspot.com/.../akuntansisektor-publik-karakteristik diakses, 29 Juli 2017.
8. Pendlebury (1992) and Hercok (1989.

State that the Central or The Local Government Funds The broad Provision of Public Goods in Most Countries. Bridges Press, New York.

9. Ronen dan Schiff. (I978). Public Sector Characteristics Organization. International Seminar in Inglish.

10. Sowerby. 1985. Dalam Narayan Chandrasekaran; Nguyen Luong Dung; Oskar Mahrenholtz. Volume 51.

11. Sterling, J. 2004. Look at Communication Theory. Robinson, J.P., dan Shaver Publish, P.R.

12. Watts, R, L., and Zimmerman, J, L. 1978. Positive Accounting Theory. New. York, Prentice Hall. Watts, R, 